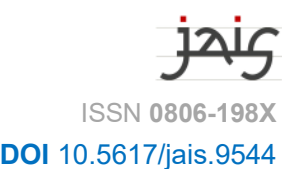

\title{
Past vs. Present
}

\section{By Mihaila Yordanova and Stephan Guth}

Assessments of the present that do without looking back to the past are rare, both in Egypt and Tunisia. Typically, people compare, either explicitly or implicitly; often, they go back to the more recent past, but there are also attempts at a long-term perspective. The comparison may come as an immediate reaction to, or comment on, a recent event or the present situation; however, five years after the revolutions, a more reflexive pondering over the achievements and drawbacks of the past few troubled years is also very common. In any case, the comparison serves certain purposes, depending on who is speaking.

In February Egyptian President Abdel Fattah el-Sisi makes a passionate plea for help. The country's economy is in trouble, but if only the ten million Egyptians with mobile phones would send one pound per day to the Tahyā Mișr (Long Live Egypt) fund, then Egypt would prosper once again (EG Independent). Although el-Sisi's words are widely ridiculed on social media [ Inferiority $=$ Superiority (Satire)] and criticised by economists doubting the campaign's viability (AGGOUR), by the beginning of March, the fund has collected 3.75 million Egyptian pounds. Moreover, a poll conducted by the Egyptian Centre for Public Opinion Research (Baseera) and published in March shows that $6 \%$ of the respondents have been donating daily, while $33 \%$ have donated at least once (el-BEHARY). The campaign, dubbed bizarre by many, seems to have resonated with Egyptians on some level. This is perhaps partly because the idea of bringing the country back on track through shared efforts fits neatly into the narrative of past and present embraced by the president and his supporters.

The relationship between "the then" and "the now" in this case is not a novelty. Its purpose is to define the common values of the present and contrast them with the recent past. It creates a sense of a common identity, which at the same time is distinct and separated from the beliefs of other groups within and outside Egyptian society. However, the past is not a homogeneous entity. The time of Mubarak or that of Nasser, for example, are not necessarily so different from the present. To many of the regime's supporters those days embody the system, the true character of the country, with el-Sisi as the natural next step (Egypt's Modern Pharaohs) [ $\nearrow$ Father Figures]. But there is one particular period of time that is often evoked to define the current state, namely the years between the January 2011 protests and the ousting of former President Muhammad Mursī or "the catastrophic chaos" of the so-called 'Arab Spring', as a person commenting on The Economist's article entitled "The ruining of Egypt" calls it (Economist). Whether it was just naïve activism or a foreign plot [ $\nearrow$ True $=$ False (Life in Limbo), $\lambda$ The Suspect Foreigner], one thing is certain, the January protests toppled a regime and brought violence and insecurity. They destabilised the country to the point of near-destruction. What is worse, they brought to power "the fascist Muslim Brotherhood and their terrorist president Morsi," a bunch of radicals on a quest to destroy all order and transform Egypt into a copy of late-Taliban-era Afghanistan. But eventually "the Egyptian people and the army intervened to impose the will of the Egyptians," el-Sisi was elected, and order was restored. A major battle was won, and the Egyptian identity was saved to prosper throughout the ages [ $\nearrow$ True vs. False].

Journal of Arabic and Islamic Studies • 21 (2021) - Themed Section In2016: *340-*352 (C) Mihaila Yordanova, Bruxelles, BE, and Stephan Guth, IKOS, Univ. of Oslo, NO 
This upbeat story sets the background against which the current is defined. In many respects, it can only exist in opposition to the thrilling narrative of the past. Now is the time for Egyptians to "put their heads down" and work towards a brighter future. It is the time to bring Egypt back to "where it was before," i.e., before 2011. Things may not be ideal at the moment-the economy is struggling and the tourists are gone [ $\nearrow$ Tourist Resorts]. But this is nothing in comparison to the violence of the Arab Spring. Besides, because of the partnership between the army and the people, the situation is improving little by little. Just look at the New Suez Canal or the projects for the poor! [ $\nearrow$ The Voice from Above]

The emphasis on the shared efforts (and responsibility) also perhaps has another function. "I didn't get out in 2011 but I participated in the other revolution," a taxi driver exclaims in August. According to him, as long as everyone continues to contribute with what they can, the future surely will be bright. "Make sure to tell your friends that there is security in Egypt," he finally remarks, as if to prove that he is playing his part (YORDANOVA). The driver's previous passivity has at some point turned into action and he is willing to spend energy and time defending a system he believes in, which was once on the verge of perishing. In this sense, there is something post-revolutionary about his demeanour, which might be part of the reason why so much attention is being paid to not calling July $3^{\text {rd }}$ a coup. The now is feverishly and patiently rebuilding a world that has been damaged. And that entails not only putting up with the pitfalls of the present, but also an unshakable belief that the path Egypt is on is a choice and it is a cause worth fighting for. It is almost like a near-death experience which has reinvigorated the will to live.

The future is also instrumental to maintaining this belief. Part of it is optimism. The new projects el-Sisi is undertaking which will soon substantially improve the quality of life [ $\nearrow$ The Voice from Above] are quoted by many as a proof that the country is going forward and that the authorities are doing their job. But part of it is fear that the past will return and that this will be the end of it all. "Do you want Egypt to turn into another Syria or Libya?" ask the regime supporters commenting on The Economist article (Economist). And this is a common refrain. One wrong move can bring Egypt back and this time, the country might not be as lucky [ ZSecurity vs. Fear]. Moreover, what makes the situation even more dangerous is the fact that there are some people in this country who want this to happen. On April 23, the Facebook group Mișr lil-gamī wa-bil-gamī (Egypt for and through Everybody) illustrates the hashtag \#al-Sīsi șāyin arḍuh (“\#el-Sisi protects his land”) [ユRed Sea Islands] with an image, presumably showing scenes from the 2011 Revolution — a building and a truck in flames — with a caption reading, "They... want this Egypt." Immediately below, another picture shows a recently renovated motorway and a photo of a newly built residential block in New Ismailia City [ $\left.\nearrow^{c} A s h w \bar{a}^{3} i y y \bar{a} t\right]$ subtly branded with "And we, who are with President el-Sisi, are building this Egypt" (FB [a]). The message is clear: stick and work with the Father who will guide Egypt to greatness and prosperity... or follow "them" on the path to disaster and devastation that we have already lived through [ $\nearrow$ Father Figures].

Commemorating the anniversary of the $25^{\text {th }}$ of January [ $\nearrow$ Commemoration / Memorial Days], the Facebook page Alexandria re-posts an updated version of its album dedicated to the revolution (FB Alexandria). Many of the images depict violence and destruction: tear gas covering the skies over Alexandria, burning trucks and governmental buildings, injured

jais • 21 (2021) - Themed Section In2016: *340-*352 
protesters walking through thick fog, pressing handkerchiefs against their faces. The comments are pouring in:

I swear it's like it was a lifetime ago. - These were the sweetest days and [they gave $\mathrm{me}$ ] the best feeling ever! - I was covered in dust and rubble. Now I regret I ever complained about it. - I wish every day was the $25^{\text {th }}$ January. (Ibid.)

The same period of time is again being contrasted to the present, but this time it is a very different past, telling a very different story.

For it is not the destruction per se that is making people fondly remember the protests. It is the feeling of absolute freedom and the power to diminish a system which was once believed to be invincible [ Inferiority vs. Superiority]. It is the sudden realisation that the "barrier of fear is broken" and that a new future is being born, one in which "Impossible is nothing" is not merely an Adidas commercial slogan. This powerful feeling of grassroots change even in the little things is captured in Ahmed Salah (Aḥmad Șalāḥ)'s recollection of the events:

Tahrir felt like a utopia. Businessmen talked with beggars. Women in designer clothes picked up garbage. People shared sandwiches with strangers and left their cell phones to charge unguarded. When Muslims gathered to pray, Coptic Christians surrounded and protected them. When the square was attacked, we ran toward the danger to help. Everyone was equal and generous and brave. (SALAH)

It was beautiful. It is hard to describe, but the energy in Tahrir felt like the opposite of mob rule. Everyone in Tahrir knew tanks could roll in and kill us. We were prepared to die for a cause, so why would we argue or act dishonestly or be anything other than the best we could be? [ $\nearrow$ Downtown/Centre-ville] (ibid.)

Both the Egyptian and the Tunisian people were ready to reclaim what was rightfully theirs. And that has many different aspects, as Samia Jaheen (Sāmiya Ğāhīn) explains, talking about protesters singing the infamous "Yà bilādī, yā bilād̄̄̄":

Of course, we sang it then. Every day. Many times, [...] And when we sang it, it actually meant something, for the first time, I think. I used to sing it all the time in school and it never meant anything, but singing it then when people were sacrificing their lives for the country-getting killed by the police [ $\nearrow$ The Policeman Criminal]—it felt different.

[Reporter:] Didn't you feel like you were singing the anthem of the very government you were protesting against?

[Sāmiya:] Yes, of course. But we were singing it to re-own it-to say, "This is our country; not yours." We didn't sing it the gentle way they sing it. We sang it like "BILADY, BILADY, BILADY." (Republic or Death)

Perhaps most important of all, the January Revolution also created a sense of belonging. It brought the emotional ecstasy that could only be achieved through collective action and through the realisation that a person's deepest fears and wildest dreams are shared by many others. It is the type of ecstasy that creates an unshakable belief in one's abilities and in the inevitability of real change. This is how Walid Akef (Walīd 'Ākif) recalls this period:

jais • 21 (2021) - Themed Section In2016: *340_*352 
After the prayer, we saw an enormous demonstration heading to the beginning of alHaram Street, where I prayed. Thousands of protesters chanted these three words, together, one after the other: Bread, freedom and human dignity. It was an amazingly indescribable scene. It was the first time in my whole life to see something like this. I had goosebumps all over my body. I had tears falling from my eyes. And I joined them. (AKEF)

The transformational power of what took place five years ago is such that those who have spent the crucial days abroad lack the essential experience that unites those who shared itto the degree that a young couple like Nadà and Ayman cannot find themselves together again when Ayman returns from a stay in Europe where he had left to study while Nadà had lived those events that were to reshape her personality once and for all. The documentary Nihāyāt $s a^{\text {‘' }} d a$ (Happily Ever After) that follows the couple's failure to renegotiate their relationship has been interpreted as a powerful metaphor of the decisiveness of the revolutionary experience. The one who has not lived it, not formed part of the revolutionary masses, cannot reconnect and eventually decides to leave the country again, partly perhaps because the Revolution not only changed Egypt and its people but also continues to capture their imagination. It is difficult nowadays to avoid glorified accounts of the early days of 2011 . The $25^{\text {th }}$ of January is constantly being dissected, every aspect of the protests is being described in detail and length, day by day and hour by hour. It is being commemorated in books and movies. Its emotional power is being recreated in numerous documentaries, such as Abadan lam nakun atfālan, Jeanne d'Arc Masriya, Amal, A Revolution in Four Seasons. Unlike the regime's supporters, who only mention the past to contrast it to the present, for the supporters of the 2011 events the past is the king. It is the centre of their discourse.

This might be partly because the present has little to offer. It is "hell after paradise" (AKEF), "the worst moments Egypt has ever lived" (ibid.), "worse than square one" (BOHN) [ $\nearrow$ Hope vs. Hell]. People now disappear from their apartments [ $\nearrow$ Disappearances], the youth are being killed, imprisoned, repressed [ $\nearrow$ Prison]. Somewhere along the way, a cosmic error has occurred, and Egypt now is like Egypt under Mubarak, only worse, more violent and less free. People have now lost their voice. "I have nothing to say: no hopes, no dreams, no fears, no warnings, no insights; nothing, absolutely nothing," writes Alla Abd alFattah ('Alā' 'Abd al-Fattāh) for The Guardian (Guardian) [ $\nearrow T$ The Voice from Above]. He cannot remember what it was like when "tomorrow seemed so full of possibility." For "now tomorrow will be exactly like today and yesterday and all the days preceding and all the days following" (ibid.), an endless cycle of despair and repression that is also shared by nonintellectuals like the slum-dwelling mother-of-four, Nādiya, in Maḥmūd Sulaymān's documentary Abadan lam nakun atfälan: reviewing her life from before the revolution until now, she describes it as an itinerary that led her from destitution to hope to disappointment to despair [ $\nearrow$ Present $=$ Past (Stuck)]. Is it that surprising that in this atmosphere, the dystopian novel genre seems to flourish $[$ \Нope $=$ Hell (Dystopia)]?

For many, the only way to make the present bearable is to indulge in remembering the past. These memories are the only anchor in a world which is rapidly spinning out of control, as painful as evoking them might be.

jais • 21 (2021) - Themed Section In2016: *340-*352 
Part of me didn't want to tweet to the hashtag [\#Jan25] — writes Rasha Abdulla (Rashā 'Abd Allāh) - I wanted it to remain intact with the beauty of the 18 days of the revolution. With its romance, and anger, and humour, and emergencies, and cries of freedom, and dreams of a better tomorrow. I didn't want the hashtag to carry the painful scars of today, the disappointment, the cries of the dead and the detained and the disappeared (ABDULLA). [ $\nearrow$ Disappearances, $\nearrow$ Prison]

But the memories are also a way to protect the past - which many perceived as being gradually erased by the regime or post-revolutionary everyday routine and negotiations - and to remind oneself that there was a time when the country was different [ $\lambda$ Commemoration / Memorial Days]. Many fictional evocations, or re-stagings, of the days that led up to or immediately followed the uprisings seem to serve this purpose of preserving the legacy of the revolution. Implicitly, without mentioning the present, productions like 'Alà hallat 'ayni / À peine j'ouvre les yeux (As I Open My Eyes), Nawwāra, Nhibbik, Hād̄̄ / Hédi, Mawlānā / The Preacher, or The Nile Hilton Incident reconfirm how timely and necessary the revolution was... and, obviously, still is - in many respects, the evils shown in these films have survived into the present, so the revolution is not completed yet. All the more important it is now to make sure that people will not forget they once had the power to topple a regime and were willing to pay a high price to do so.

Writing is one of the weapons I rely on to confront the ongoing and expected betrayals to memory — writes Sabah Hamamou (Șabāḥ Hamāmū) on the so-called Camel Battle.

- I don't want its memory to be betrayed. I want it to stay alive, I want the emotions I felt that night - and that I experience anew as I type these words-to resist disappearing as the years pass by... To fight forgetting, write what must not be forgotten! (HAMAMOU)

The memories are also a way to continue the revolution in a way. As Rasha Abdullah puts it, it is a way to "get your head above what's happening for a breath of fresh air" (ABDULLAH) [ オInferiority vs. Superiority]. She describes realising that it is precisely the spirit of the revolution that the regime is most afraid of and constantly reminding them that the fire continues to burn is the only way to bear the present and even change the future:

Is the revolution over? I don't think so. The revolution goes on in the hearts of those who believe in the values of bread, freedom, and social justice. Has the revolution failed? I don't think so. It certainly depends on your definition of revolution, and for me, it's a long-term process that starts with the individual. I have my own revolution to carry on inside. (ibid.)

Here the past is not used to justify and explain the present, but rather to fight its normalisation. And while in the regime's discourse, the present cannot exist without the threat of the past, here the message seems to be that a person cannot exist in this present without the memory of the past. The restaging of the violent clashes during the Mursī period between Muslim Brothers and secularists in the dramatic movie Ishtiba $k$ [ $\nearrow$ Clash] serves a similar function: How will society ever be able to overcome social fragmentation and find a way to reconciliation if it does not face the events of the past and grasp the chance to learn from history?

jais 21 (2021) - Themed Section In2016: *340-*352 
To do that, however, a cool, detached approach seems to work best. There is a difference between remembrance, preservation and documentation and idealisation. For Ahmed Naji the greatest obstacle to bringing the revolution back on track are not the "beasts" and "zombies" intent on sucking out the last bit of free space left to the youth. It is nostalgia: the perilous belief that a perfect past once existed, coupled with the unfulfillable desire to bring that past back. The sorrows and ghosts that lurk in the shadows of the bittersweet semi-reality in which the nostalgic prefers to exist, are impairing the youths' vision, preventing them from finding "a new path and revolution". "Any form of reverence-for the revolution or the martyrs or higher ideologies - is enough to turn you into a zombie without even noticing it", Naji's final advice rings from his "Farewell to the Youth". It is the last, but most treacherous trap laid on the path to change and it seems to have already claimed some victims...

And then there are those narratives that oscillate between the pros and cons of the revolution. Maḥmūd Sulaymān's movie We Have Never Been Kids documents Nādiya's and her children's lives from before the revolution until 2015 where Nādiya, who had participated in the demonstrations and later elections, now no longer sees a point in going to the polls. "We are back to the situation as it was under Mubarak: we are no longer part of the game," she explains her decision. There is not that much of an opposition between past and present here. For many Egyptians struggling to keep their families and lives afloat, the hopes and dreams only end up in disappointment, the past is the same as the present and the future, and nothing will ever change. At some point, continuing to expect something becomes meaningless $[\lambda$ Present $=$ Past (Stuck) $]$ or even painful. The fundamentally sober insight that "hope is hell," which is the central message of Muhammad Rabī's IPAF 2016-shortlisted dystopian novel 'Utârid still proves to be true although the author's vision is older than a year now.

Somewhere in-between are also the many narratives that combine an essentially positive attitude towards the uprisings of 2010/2011 with the description of severe traumata suffered during the events. Jeanne d'Arc Misriya is such a cautious attempt to document the impact of violence a number of young Egyptian women became victims of during the revolution: what they have been through, for the sake of freedom from despotism and human dignity, has left deep imprints on their lives, wounds that almost do not cicatrise, a burden from the past that these women are still carrying in the present. - The Tunisian feature film Ghadwa hayy / Demain dès l'aube addresses another such aspect. As the result of a tragic course of events, young innocent demonstrators have become themselves guilty of brutal violence and an ensuing human tragedy: when a police-officer had started to rape a young demonstrator [ $\nearrow$ The Policeman Criminal] they had beaten him so severely that he will be dependent on a wheelchair for the rest of his life. - Shaykh Jackson, on the other hand, starts out as the accusation of a despotic father who destroys the youth of his son only because the boy is a fan of Michael Jackson; the son is so traumatized that he seeks professional help [ $\nearrow$ Psychiatrists]. However, the healing process is not accomplished until the son, after many years of separation, goes to see his father, starts to understand that the latter also suffered deeply, and a process of reconciliation can be initiated. - Facing the traumatic past as personified in a dominant father seems to be the key for a turn to improvement and a solution to cope with what has happened also in the Tunisian Shbābik al-janna / Les frontières du ciel (Borders of Heaven). Here, a young couple (= the Tunisian youth) had a 5-year-old child

jais • 21 (2021) - Themed Section In2016: *340-*352 
called "Yāsmīn" (= the "Jasmine" Revolution) whom they adored but who one day was taken by the sea in a moment of its parents' inattention. How to deal with the traumatic loss of little Jasmine who was the source of all the young couple's pride, their identity and dreams for the future? While the woman after a while finds a way to put the sweet memories of an irretrievably lost past aside and gradually regain the present, the image of Jasmine that is constantly appearing before the man's eyes ceases to haunt him only after he has paid a visit to his dying father [ $\nearrow$ Father Figures] with whom he had broken years ago-a moment of reconciliation, also here, as a precondition to find a way back to life in a completely disenchanted present.

The parental adoration of little Yāsmīn does reflect to an extent the way many Tunisians perceive the past and particularly the Jasmine revolution. For some, like Lilia Ben Messaoud and Hajer Korbi, the revolution was mostly a success story. Behind the façade of prosperity in Ben Ali's Tunisia lurked the shadow of a corrupt and unscrupulous government, an authoritarian and repressive regime, in which no freedom of expression, press or assembly could ever exist. Fed up with its failures, Tunisians finally took to the streets, demanding their dignity, freedom and bread back and ultimately succeeded in ousting the dictator. While many challenges remain, the civil society will continue pushing for change, making sure that the police state never again returns (BEN MASSAOUD \& KOBRI). A similar, while not as upbeat, point is made in Leyla Bouzid's As I Open My Eyes, released on the anniversary of the Revolution. While not directly dealing with the 2010-2011 events, the movie nevertheless shows why the protests happened and, indeed, why it was inevitable for them to happen, by exploring the influence the Ben Ali regime exercised over the lives of ordinary Tunisians and the way it attempted to suppress any dissent. As Rim Ben Fraj notes, the movie is actually an artistic cry against the nostalgia and amnesia so prominent in Tunisian society these days (BEN FRAJ). Like Nhibbik Hādi / Hédi, but also Egyptian productions that restage the situation on the eve of the revolution in a similar way, like Mawlānā or The Nile Hilton Incident, not a few feature films try to keep the memory of the revolution alive, evidently because they think that tasks like working towards more social justice, or against the power structures of the old regimes, or for the formation of a sense of individual responsibility for one's own future are still waiting to be fulfilled.

These voices work against a deeply entrenched feeling, widespread not only in Egypt but also among many Tunisians, that the Revolution should not have happened. For Laryssa Chomiak, this is connected to the idea that something fundamental is lacking in the present and rapid reform is needed to address the issue. What is even more troubling, this "reformfocused emphasis based on absence and inadequacy" has shifted popular perception, leading many to believe that it would be better if things went back to where they were (CHOMIAK). After all, as the proponents of this idea will say, most people had "a comfortable life under Ben Ali," the country was safe and secure and the economy was doing better (LAGEMAN). And all this "left with him" (BEN HMIDA).

Then there are also those who, while not seeing much change in their lives now, still do not think that the uprising was a mistake. For many of the young Tunisians who participated in it, for example, the revolt, while justified, just did not meet its goals. Looking at the aging representatives of the government, many believe that the revolution, which was largely provoked by the grievances of the youth, was hijacked by the political elites. "There was a

jaig • 21 (2021) - Themed Section In2016: *340-*352 
revolution in Tunisia and Kasserine, and it got stolen by political parties that didn't know what they were doing - first Ennahdha, then Nidaa Tounes," government worker Chokri Slougui is quoted as saying in a New Yorker article (PACKER). The same sentence is repeated once more in the article by civil activist Ons Ben Abdelkarim (Uns Bin 'Abd al-Karīm), talking about young Tunisians leaving their country to fight in Syria. Feeling marginalised and cheated, the revolutionary youth feel "stuck" in a present which has failed to live up to their earlier expectations [ $\nearrow$ Present $=$ Past (Stuck)]. However, the past seems to affect youth radicalisation in other ways, as well. In the movie Zahrat Halab (The Flower of Aleppo), the youth's readiness to join Islamist militants in Syria is linked to a problematic father figure (here, it is not the patriarch-despot but its 'contrary', the drinking artistintellectual whom the son cannot respect as an authority.) Some, like the blogger_Z, try to escape the situation by reliving the days of the revolution, calling for a return to the true ideals of the uprising (DEBATunisie). Others find a different way out [ $\nearrow$ Hashish, $\lambda$ Migration]: $\bar{A} k h i r$ wăhid fina $\bar{a}$ (The Last of Us) enacts the story of a young man who cuts all bonds with the past to be free to start into a completely new future; after a painful period of transition, learning and adaptation to a fundamentally different, savage and hostile world, the film - a story of formation of the self — ends with the youth's 'rebirth' as a free and independent, mature and self-confident strong man.

A similar relationship is present in Egyptians' and Tunisians' daily lives on a different level. These days a wave of nostalgia is spreading around the two countries. People like to remember the good old days. For some in Egypt, those are the days of Nasser, when the country was a regional stronghold $(F B[\mathrm{~b}])$ and the poor were cared for and treated with respect $(F B[\mathrm{c}])$, when real movies were made, literature and culture were flourishing (MadàMașr) and Egypt had the "Bolshoy Five," a pioneering group of ballet dancers (A Footnote on Ballet History) and the Arabic music was authentic. For others, the glorious days of the Egyptian monarchy, with its lavish parties, liberal outlook and beautifully maintained gardens, streets and public spaces, were the golden ages ( $F B[\mathrm{~d}] ; F B[\mathrm{e}] ; F B[\mathrm{f}])$. In Tunisia, many long for the times when Bourguiba was in office, working tirelessly to modernise Tunisia and eradicate social and gender inequality (ArabWeekly). This was also the time when Tunisia took the lead in the Third World cinema movement and the great Tahar Cheriaa initiated the famous Carthage Film Festival (Tahar Chariaa: Taht zilāl al-bāwbāb / A l'ombre du baobab). It seems that all kinds of minorities - religious, ethnic, social, artistic, intellectual-are especially prone to this type of nostalgia. We are Egyptian Armenians, for instance, is an extensive documentation about the Armenian community's longstanding contribution to the history and culture of the country on the Nile. The compatibility of Armenian and Egyptian identity is underlined all along the film, as if to prevent, in anticipation, any attempt on the side of post-revolutionary society to try to exclude the marginal group from further participation in national life, or to appeal to any government not to neglect protecting them if so needed (and the need may easily arise, as not only the documentary al-Salāt wa'l-ma'raka / La Vallée du Sel about a Christian couple who is receiving death threats from some Jihadist youth during the Mursī years makes clear). But also, the more recent past is admired, and not only by minorities. For example, many yearn for the times when the streets of Cairo and the coastal towns of Tunisia were still filled with thousands of happy tourists [ $\nearrow$ Tourist Resorts].

jais • 21 (2021) - Themed Section In2016: *340-*352 
Now? Now there is none of this. The streets of Egypt are filthy and full of $\lambda$ Garbage, people live in poverty and no one gives a damn, the tourists are gone, the economy is struggling, art is either pretentious or lacks any merit [ 7 Beautiful vs. Ugly] and the politicians have no clear plan for the future and do not really care about making the situation better. These days, even music is difficult to enjoy [ $\nearrow$ Pop Music].

The nostalgics on all sides of the aisle have this in common. They all inevitably contrast their idealised view of the past to the pitfalls of the present. The picture does not have to be accurate. Stories and pictures could be fabricated, as long as they fit with the imagined reality of the days gone by, like the fake story of Nasser serving as a guardian to a desperate young bride [ $\nearrow$ Father Figures]. For in many ways, nostalgia is as much an admiration of the past as it is a critique of the present. It might be just a person mourning their lost youth or parents sensing that they are losing their connection to the younger generation (YS, Feb. 11). But in many cases, nostalgia can take a political turn.

In April, protests erupt in Egypt over the transfer of the two Red Sea Islands of Tìrān and Șanāfïr to Saudi Arabia [ $\nearrow$ Red Sea Islands]. Egyptians are furious with the government's decision and the Facebook admirers of the monarchy and Nasser are no exception. On April 13, The Official Page of King Fārüq posts a 1950 letter, supposedly a response from the Foreign Ministry to the Ministry of War, stating that the ownership of the two Red Sea islands is Egyptian $(F B[g])$. On April 16, a Facebook page dedicated to Nasser posts a video in which the former president states that Tìrān is Egyptian $(F B[\mathrm{~h}])$. Both pages attempt to prove that what is happening is wrong and to justify their discontent with the decision. But in order to do that with absolute certainty, they rely on contrasting the current actions of the Egyptian government with the realities of their respective pasts. Many of the black-and-white photos, historical anecdotes and documents posted online, depict a beautiful and flawless picture of a perfect past, which stood for certain values, such as social justice, dignity or liberalism. This image is then contrasted to the present, perceived as lacking these values. It is simultaneously a proof that a better yesterday once existed and an implicit critique of the political elites, which have allowed this past to vanish. In many respects, nostalgia justifies people's discontent with the present and serves as a vehicle of expressing it.

But the past can serve the opposite function as well. Talking about street harassment in Egypt, that problems persist. The government is taking steps to contain the feminist movement and is discriminating against the LGBT community [ 7 LGBT]. Yet, so many things have improved, compared to the situation ten years ago. People's perception of sexual violence is changing, women are starting to complain to the police en masse and the advertisement business, once dominated by sexism, is taking some decidedly positive steps forward (ABDelhameEd) [ $\lambda$ Male $v$ s. Female]. Similarly, in Tunisia, amid criticism of the current government, Facebook users acknowledge that the work of the Truth and Justice Committee, charged with gathering information about the victims of the Ben Ali regime, is after all a good thing. Civil activist Omar Fassatoui, for example, notes:

Whether we say that it could have been better ... one fact remains ... We have started a huge work on the Tunisian collective memory, and I hope for national reconciliation. [ TPublic Hearings] 
In both cases, the current situation is perceived as unsatisfactory. But a "bad" present is contrasted to an inferior past, to emphasise a positive development. Things are far from ideal, but some steps in the right direction are being taken. Yet, as always, the only way to fully grasp what the present has to offer is to have a good, long look at the past.

\section{Related Entries}

ARRAYs - 'Ashwä'iyyāt • Clash - Commemoration / Memorial Days • Disappearances

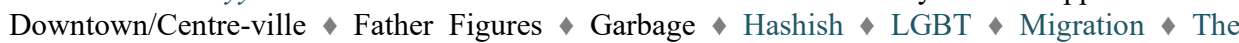
Policeman Criminal $\downarrow$ Pop Music $\downarrow$ Prison $\downarrow$ Psychiatrists $\downarrow$ Public Hearings $\downarrow$ Red Sea Islands The Suspect Foreigner Tourist Resorts $\downarrow$ The Voice from Above

Codes - Beautiful vs. Ugly Hope $v s$. Hell $\downarrow$ Inferiority vs. Superiority Male vs. Female Security vs. Fear True vs. False The Voice from Above

CODES ColLAPSED - Hope $=$ Hell $($ Dystopia $) \diamond$ Inferiority $=$ Superiority $($ Satire $) \diamond$ Present $=$ Past $($ Stuck $)$ $\checkmark$ True $=$ False $($ Life in Limbo)

\section{References}

\section{Written}

Abdelhameed, Dalia. "For the Women of Egypt, Today Is Not like Yesterday." MadàMașr, March 8, 2016, <https:/www.madamasr.com/en/2016/03/08/opinion/society/for-the-women-of-egypt-todayis-not-like-yesterday/>.

ABdullah, Rasha. “The Egyptian Regime Is Afraid Because the Revolution Isn't Over." Public Radio International (PRI), January 26, 2016, <https://www.pri.org/stories/2016-01-26/egyptian-regimeafraid-because-revolution-isnt-over>.

Aggour, Sara. "Different Names, Same Purpose: The Long History of Patriotic Donations." Daily News Egypt, March 8, 2016, <https://dailynewsegypt.com/2016/03/08/different-names-purposelong-history-patriotic-donations/>.

AKef, Walid. " 5 Years After the Revolution, Egypt's a Hell After a Paradise." Huffington Post, January 26, 2016, <https://www.huffingtonpost.com/walid-akef-/egypt-revolution-anniversary b_9081840.html>.

$[$ ArabWeekly $=]$ N. N. "Fear of Islamism behind Nostalgia for Bourguiba." The Arab Weekly, 8 April 2016, <https://thearabweekly.com/fear-islamism-behind-nostalgia-bourguiba>.

el-BEHARY, Hend. "Only 6\% of Egyptians Donated LE 1 Daily to Tahya Masr Fund: Baseera." Egypt Independent, March 20, 2016, <https:/www.egyptindependent.com/only-6-egyptians-donated-le1-daily-tahya-masr-fund-baseera/>.

BEN FrAJ, Rim. “À Peine j'ouvre les yeux : Un film contre l'amnesie et la nostalgie.” Nawaat, March 29, 2016, <https://nawaat.org/portail/2016/03/29/a-peine-jouvre-les-yeux-un-film-contre-lamnesie -et-la-nostalgie/>.

BEN HMIDA, Cheima. "Five Years On, Tunisians Share Memories from the Jasmine Revolution." Huffington Post, January 15, 2016, <https:/www.huffingtonpost.com/entry/jasmine-revolutiontunisia-anniversary_us_56993211e4b0b4eb759e367c?guccounter=1>.

Ben Massaoud, Lilia and Hajer Kobri. "Voices: Tunisia's 'Arab Spring' Revolution Remains Incomplete." USA Today, August 29, 2016, <https://eu.usatoday.com/story/opinion/voices/ 2016/08/29/tunisia-arab-spring-revolution-free-speech/89394910/>.

jais • 21 (2021) - Themed Section In2016: *340-*352 
BoHn, Lauren. “A Revolution Devours Its Children.” The Atlantic, January 23, 2016, <https://www. theatlantic.com/international/archive/2016/01/egypt-revolution-arab-spring/426609/>.

Chomiak, Laryssa. "Five Years after the Tunisian Revolution, Political Frustration Doesn't Diminish Progress," January 14, 2016, <https://www.washingtonpost.com/news/monkey-cage/wp/2016/01/ 14/five-years-after-the-tunisian-revolution/?utm_term=.ca269a9435a0>.

[DEBATunisie =] N. N. "Révolution ?" DEBATunisie, January 14, 2016, <http://www.debatunisie. com/archives/2016/01/14/33208125.html>.

$[$ Economist $=$ ] N. N. "After the Arab Spring: The Ruining of Egypt." The Economist, August 6, 2016, sec. Readers' Comments. <https://www.economist.com/comment/3213235\#comment-3213235>.

[EG Independent =] N. N. "Sisi’s 'Egypt Vision 2030' Speech Garners Positive, Negative Reactions.' Egypt Independent, February 25, 2016, <https://www.egyptindependent.com/sisi-s-egypt-vision2030-speech-garners-positive-negative-reactions/>.

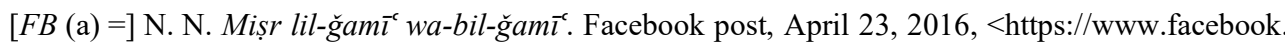
com/1 Tamer.Asfour/photos/a.363452263709580.90414.152451254809683/985198328201634/?ty $\mathrm{pe}=3>$.

$[F B(b)=]$ N. N. Gamāl 'Abd al-Nāṣir. Facebook post, March 20, 2016, <https://www.facebook.com/ naseer56/posts/10154896828124368:0>.

$[F B(\mathrm{c})=]$ N. N. Gamāl 'Abd al-Nāṣir. Facebook post, February 7, 2016, <https://www.facebook. com/naseer56/posts/10154777433924368:0>.

$[F B(\mathrm{~d})=]$ N. N. Al-Ṣaf̣̆a al-rasmiyya li-mawqi ${ }^{c}$ al-malik Fārūq al-awwal, Fārūq Mișr. Facebook post, December $\quad 30, \quad 2016, \quad<$ https://www.facebook.com/king.farouk.faroukmisr/photos/a. 116859731748670.14224.102433933191250/1034585216642779/?type=3\&theater $>$.

[FB (e) =] N. N. Al-Șafḥa al-rasmiyya li-mawqi c al-malik Fārūq al-'awwal, Fārūq Mișr. Facebook post, January $25, \quad 2016, \quad<$ https://www.facebook.com/king.farouk.faroukmisr/photos/a $116859731748670.14224 .102433933191250 / 809033145864655 /$ ?type=3\&theater $>$.

[FB (f) $=]$ N. N. Al-Ṣafḥa al-rasmiyya li-mawqi cal-malik Fārūq al-awwal, Fārūq Miṣr. Facebook post, October 14, 2016, <https:/www.facebook.com/king.farouk.faroukmisr/photos/a.116859731748670. 14224.102433933191250/965994060168562/?type=3\&theater $>$.

[FB $(\mathrm{g})=]$ N. N. Al-Safha al-rasmiyya li-mawqi al-malik Fārūq al-'awwal, Fārūq Mișr. Facebook post, April 13, 2016, <https:/www.facebook.com/king.farouk.faroukmisr/photos/a.116859731748670. 14224.102433933191250/850145965086706/?type=3\&theater>.

$[F B(\mathrm{~h})=]$ N. N. Gamāl 'Abd al-Nāṣir. Facebook post, April 6, 2016, <https://www.facebook.com/g. abdalnasr56/posts/794927797308275>.

[FB Alexandria =] N. N. Facebook Group Alexandria. "25 January Revolution (Album)." Facebook page, [n.d.], 2016, <https://www.facebook.com/pg/Alexandria.EgyptOfficial/photos/?tab=album \&album_id=10152190240003516>.

[Guardian =] N. N. "I Was Terribly Wrong'-Writers Look Back at the Arab Spring Five Years On." The Guardian, January 23, 2016, <https://www.theguardian.com/books/2016/jan/23/arab-springfive-years-on-writers-look-back>.

Hamamou, Sabah. "The Only Weapon We Have Is Memory: Remembering The Camel Battle." Huffington Post, May 2, 2016, <https://www.huffingtonpost.com/sabah-hamamo/the-onlyweapon-we-have-i_b_9167332.html>.

Lageman, Thessa. "Nostalgia for Ben Ali and Hopes for New Revolution in Riot-Stricken Tunis Suburb.” Middle East Eye, January 25, 2016, < https://www.middleeasteye.net/news/nostalgia-benali-and-hopes-new-revolution-riot-stricken-tunis-suburb-2045183542>.

jais 21 (2021) - Themed Section In2016: *340-*352 
[MadàMașr =] N. N. "The Fantasy of the Past: A Conversation with Graphic Novelist Lamia Ziade." MadàMașr, May 30, 2016, <https://www.madamasr.com/en/2016/05/30/feature/culture/thefantasy-of-the-past-a-conversation-with-graphic-novelist-lamia-ziade/>.

PACKER, George. "Exploring Jihad: The Arab Spring Has given Tunisians the Freedom to Act on Their Unhappiness." The New Yorker, March 28, 2016, <https://www.newyorker.com/magazine/ 2016/03/28/tunisia-and-the-fall-after-the-arab-spring>.

RABĪ', Muhammad. 'Uțārid. Al-Qāhira-Bayrūt-Tūnis: Dār al-Tanwīr, 2014. - Translated as Mohammed RABIE, Otared, tr. by Robin Moger, Cairo: American University in Cairo Press, 2016. (Shortlisted for the 2016 IPAF).

[Republic or Death=] N. N. "Memories of a Revolution That Failed: The Fifth Anniversary of Tahrir Square." Republic or Death, January 25, 2016, <https://republicordeath.wordpress.com/2016/01/ 25/memories-of-a-revolution-that-failed-the-fifth-anniversary-of-tahrir-square/>.

SAlaH, Ahmed. "How I Went From Leading the Egyptian Revolution to Making Minimum Wage in San Francisco." Priceonomics, April 4, 2016, <https://priceonomics.com/how-i-went-fromleading-the-egyptian-revolution-to/>.

[YS, Feb. $11=$ = N. N. "10 gumal ta kis țabī at al-ab al-miṣrī al-aṣîl: bi-ṣawt Ḥusnī Mubārak." al-Yawm

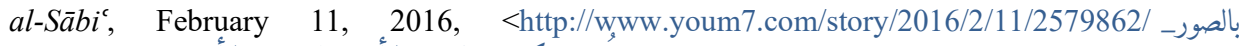

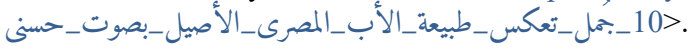

YoRDANOVA, Mihaila. Fieldwork Notes (unpublished). August 2016.

Movies

Abadan lam nakun atfālan (We Have Never Been Kids). Documentary by Maḥmūd Sulaymān (Mahmood Soliman). EG, U.A.E., Qatar, RL 2016.

Ākhir wāhid fiñā ("The Last of Us"). By 'Alā' al-Dīn Salīm (Ala Eddine Slim). TN, Qatar, U.A.E., RL 2016.

'Alà hallat 'aynī / À peine j'ouvre les yeux (As I Open My Eyes). By Leyla Bouzid. TN, F, B 2015.

Amal. Documentary by Muḥammad Șiyām (Mohamed Siam). EG, RL, DE, F, NO 2017.

Egypt's Modern Pharaohs. Documentary trilogy by Jīhān al-Ṭāhirī (Jihan El-Tahri). EG, F, USA, Qatar 2015/2016.

A Footnote on Ballet History. Documentary by Hisham Abdel Khalek. EG, USA, F 2016.

Ghadwa hayy / Demain dès l'aube (Burning Hope). By Luṭī Āshūr (Lotfi Achour). TN 2016.

Ishtibāk (Clash). By Muhammad Diyāb (Mohamed Diab). EG, DE, F 2016.

Jeanne d'Arc Masriya / Egyptian Jeanne d'Arc. Documentary by Īmān Kāmil (Iman Kamel). EG, DE, Kuwait, Qatar 2016.

Mawlānā (Our Master) / The Preacher. By Magdī Ahmad 'Alī (Magdy Ahmed Ali). EG, U.A.E. 2016.

Nawwāra (Nawara). By Hāla Khalīl (Hala Khalil). EG 2016.

Nhibbik, Hādī / Hédi (Hedi). By Muḥammad Bin 'Ațiyya (Mohamed Ben Attia). TN, B, F 2016.

Nihāyāt sa'īda (Happily Ever After). Documentary by Nadà Riyāẹ (Nadà Riyadh) and Ayman al-Amīr (Ayman El Amir). EG 2016.

The Nile Hilton Incident. By Ṭāriq Șālih (Tarik Saleh). EG, DE, SE, DK 2017.

A Revolution in Four Seasons. Documentary by Jessie Deeter. TN, USA 2016.

al-Salāt wa'l-ma'raka / La Vallée du Sel (Prayer and Battle / The Valley of Salt). Documentary by Christophe Majdī Șābir (Magdy Saber). EG, CH 2016.

Shbābik al-janna / Les frontiers du ciel (Borders of heaven). By Fāris Na'nāc (Farès Naanaa). TN, U.A.E. 2015.

jais • 21 (2021) - Themed Section In2016: *340-*352 


\section{CODES $•$ Past vs. Present}

Sheikh Jackson. By 'Amr Salāma (Amr Salama). EG 2017.

Tahar Cheriaa: Taht zilāl al-bāwbāb/ A l'ombre du baobab (At the baobab's shadow). Documentary by Muhammad Shallūf (Mohamed Challouf). TN 2015.

We are Egyptian Armenians. Documentary by Waheed Sobhi and Hanan Ezzat. EG 2016

Zahrat Halab (The Flower of Aleppo). By Riḍà Bāhī (Ridha Behi). TN 2016.

\mly201@yahoo.co.uk

\stephan.guth@ikos.uio.no 